COGNITIVE STUdies | ÉTUdES COGNITIVES, 15: 327-334

DOI : $10.11649 / \mathrm{cs} .2015 .022$

\author{
RADOVAN GARABÍK ${ }^{1, A} \&$ LUDMILA DIMITROVA ${ }^{2, B}$ \\ ${ }^{1}$ L. Štúr Institute of Linguistics, Slovak Academy of Sciences, Bratislava, Slovakia \\ ${ }^{2}$ Institute of Mathematics and Informatics, Bulgarian Academy of Sciences, Sofia, Bulgaria \\ ${ }^{A}$ garabik@kassiopeia.juls.savba.sk $;{ }^{B}$ ludmila@cc.bas.bg
}

\title{
EXTRACTION AND PRESENTATION OF BILINGUAL CORRESPONDENCES FROM SLOVAK-BULGARIAN PARALLEL CORPUS
}

\begin{abstract}
In this paper the results of the automatic extraction and presentation of bilingual correspondences from Slovak-Bulgarian Parallel corpus are described. The equivalent phrases are extracted from sentence and word level automatically aligned corpus, filtered, indexed and presented in a dictionary-like interface. The bilingual dictionary database contains 80 thousand phrase pairs consisting of approximately 350 thousand words (per each language). Counting unique word forms, the size is 31 thousand in the Slovak part of the dictionary, 26 thousand in the Bulgarian part.

Keywords: translation equivalents; GIZA ++; parallel corpora; aligned text; Slovak; Bulgarian
\end{abstract}

\section{Introduction}

In this article the authors describe the results of an experimental study on the Slovak-Bulgarian/Bulgarian-Slovak parallel corpus, prepared under the collaborative work in the frame of the Joint research project "Electronic Corpora - Contrastive Study with Focus on Design of Bulgarian-Slovak Digital Language Resources" between the Institute of Mathematics and Informatics at the Bulgarian Academy of Sciences and Ludovít Štúr Institute of Linguistics of the Slovak Academy of Sciences. The first joint study under this project consists of the analysis of differences between the Bulgarian and Slovak languages in the MULTEXT-East morphology tagset for corpora annotation (Garabík, Majchráková, \& Dimitrova, 2009). The second study is a corpus-based experiment, focusing on the analysis of automatic extraction and visualization of translation equivalents of SlovakBulgarian/Bulgarian-Slovak parallel texts with the ultimate goal to obtain useful 


\begin{tabular}{|c|c|c|c|c|c|}
\hline \multirow[t]{2}{*}{$\begin{array}{l}\text { New query } \\
\text { Word List }\end{array}$} & & \multicolumn{4}{|c|}{ Hits: 11,709 ( 137.84 i.p.m.; related to the whole corpus) I ARF: 2,617 । Result is shuffled } \\
\hline & (?) & Page 1 & of 586 Go Next I Last & & \\
\hline$\underline{\text { Save }}$ & (?) & $0 j 23385$ & $\frac{\text { skbg-free-0.1-bg }}{41120000-6 \text { Непитейна вода }}$ & oj23385 & $\frac{\text { skbg-free-0.1-sk }}{41120000-6 \text { Nepitná voda }}$ \\
\hline $\begin{array}{l}\text { View } \\
\qquad \begin{array}{l}\text { Custom } \\
\text { KWIC } \\
\text { Sentence }\end{array}\end{array}$ & & oj27341 & $\begin{array}{l}\text { Препаратите за лъскане на стъкло, които } \\
\text { са съставени обикновено от вода, от } \\
\text { алкохол, от малко количество амонячна } \\
\text { вода или от киселини ( оксалова, винена и } \\
\text { други ) и от мек абразив ; }\end{array}$ & oj27341 & $\begin{array}{l}\text { 1. leštidlá na sklo obsahujúce spravidla } \\
\text { vodu, alkohol a malé množstvo amoniaku } \\
\text { alebo kyseliny ( napr. št'avelovej alebo } \\
\text { vínnej ) a jemné brúsivo ; }\end{array}$ \\
\hline $\begin{array}{l}\text { Alignment } \\
\text { Sort } \\
\text { Custom } \\
\text { Left I Right }\end{array}$ & & oj78333 & $\begin{array}{l}\text { Doxivex } 10 \text { \% Доксициклин хиклат } 100 \mathrm{mg} / \\
\text { ml Концентрат за перорален разтвор пилета } \\
\text { ( бройлери ) } 0,5-1,0 \mathrm{ml} \text { продукт / } 1 \\
\text { литър вода за пиене . } 50-100 \mathrm{mg} \\
\text { доксициклин хиклат / } 1 \text { литър вода за } \\
\text { пиене / ден за } 3-5 \text { дни }\end{array}$ & oj78333 & $\begin{array}{l}\text { Doxivex } 10 \% \text { Doxycyklín hyklát } 100 \mathrm{mg} / \mathrm{ml} \\
\text { Koncentrát na perorálny roztok Kurčatá ( } \\
\text { brojlery ) } 0,5-1,0 \mathrm{ml} \text { lieku } / 1 \mathrm{l} \text { pitnej } \\
\text { vody } 50-100 \mathrm{mg} \text { doxycyklín hyklátu / } 1 \mathrm{l} \\
\text { pitnej vody / deñ , počas } 3 \cdot 5 \text { dní }\end{array}$ \\
\hline $\begin{array}{l}\text { Node } \\
\text { References } \\
\underline{\text { Shuffle }}\end{array}$ & & oj5979 & $\begin{array}{l}\text { Посредством стандартния процес на } \\
\text { обработка на питейната вода ( озониране ) } \\
\text { този метаболит се превръща в нитрозамин ( } \\
\text { NDMA ), който е вреден за здравето. }\end{array}$ & oj5979 & $\begin{array}{l}\text { Štandardným procesom na úpravu pitnej } \\
\text { vody ( ozonizovanie ) sa tento metabolit } \\
\text { premienha na nitrosamin ( NDMA ), ktorý je } \\
\text { škodlivý pre zdravie. }\end{array}$ \\
\hline $\begin{array}{l}\text { Filter } \\
\text { Frequency } \\
\text { Custom } \\
\frac{\text { Node tags }}{\text { Node forms }}\end{array}$ & & oj28784 & $\begin{array}{l}\text { Най - високото допустимо водно } \\
\text { съдържание на разфасовките от домашни } \\
\text { птици се определя въз основа на } \\
\text { съдържанието на белтъчини на } \\
\text { разфасовките, което може да бъде } \\
\text { свързано с естественото съдържание на } \\
\text { вода. }\end{array}$ & oj28784 & $\begin{array}{l}\text { Najvyšší povolený celkový obsah vody v } \\
\text { dieloch hydiny sa určí na základe obsahu } \\
\text { bielkovín v kusoch, ktorý sa môže } \\
\text { vzt'ahovat' na obsah fyziologickej vody. }\end{array}$ \\
\hline $\begin{array}{l}\text { Doc IDs } \\
\text { Collocations } \\
\text { ConcDesc }\end{array}$ & & oj53788 & $\begin{array}{l}\text { Директива } 77 \text { / } 649 \text { / ЕИО на Съвета от } 27 \\
\text { септември } 1977 \text { г . за сближаване на } \\
\text { законодателствата на държавите - членки } \\
\text { относно зрителното поле на водачите на } \\
\text { моторни превозни средства }\end{array}$ & oj53788 & $\begin{array}{l}\text { smernica Rady } 77 \text { / } 649 \text { / EHS z } 27 \text {. } \\
\text { septembra } 1977 \text { o aproximácii právnych } \\
\text { predpisov členských štátov týkajúcich sa } \\
\text { výhladu vodičov motorových vozidiel }\end{array}$ \\
\hline
\end{tabular}

Figure 1: NoSketch interface to the parallel corpus, query word вода.

information about Slovak translation equivalents of (definite) articles and demonstrative pronouns in Bulgarian (Dimitrova \& Garabík, 2014).

\section{Slovak-Bulgarian/Bulgarian-Slovak Parallel Corpus}

The parallel sentence-aligned Slovak-Bulgarian/Bulgarian-Slovak corpus is currently under development as a bilingual resource for different kind of language analysis, for research and development of machine and human translation systems, automatic term extraction, etc. A recent version of the corpus is available via a NoSketch Engine web interface at http://korpus.sk/skbg.html.

The corpus consists of two parts, fiction texts of about 650 thousand words and over 82 million words (in Bulgarian) and 85 million words (in Slovak) of texts of the EU \& EC journals and documents (Dimitrova \& Garabík, 2011, 2012).

\subsection{Corpus Structure}

The corpus currently contains translations of fiction in both languages, either from Slovak into Bulgarian or from Bulgarian into Slovak. The main part of parallel corpus contains texts in other languages translated into both Bulgarian and Slovak. The corpus consists of two subcorpora: direct and translated.

The direct Bulgarian-Slovak parallel sentence-aligned subcorpus consists of original texts in Bulgarian, such as novels and short stories by Bulgarian writers and their translation in Slovak, and original texts in Slovak, such as literary works by Slovak writers and their translation in Bulgarian. The set of aligned texts includes two Bulgarian novels: Dimitŭr Dimov's Осъдени души (Doomed Souls), Pavel Vezhinov's Барuepama (The Barrier) and their Slovak translations, the novel of 
Slovak writer Klára Jarunková Brat mlčanlivého vlka (The silent wolf's brother) and its Bulgarian translation.

The translated Bulgarian-Slovak parallel subcorpus consists of Bulgarian and Slovak translations of works into a third language, namely the Slovak and Bulgarian translations of Jaroslav Hašek's Osudy dobrého vojáka Švejka za světové války (The Good Soldier Švejk) and a set of texts of the EU\&EC journals and documents.

Recently, the texts of Bulgarian novel - Pavel Vezhinov's Нощем с белите коне (In the night riding the white horses), and Iordan Iovkov's short stories $\Pi$ сента на колелетата (The Song of Wheels), Вечери в Антимовския хан (Inn at Antimovo), Ако можеха да говорят (If they could talk), Женско сгрие (Women heart) and their Slovak translations were also included in the direct BulgarianSlovak subcorpus. The volume of the literature parallel texts is about 650 thousand words per language.

\subsection{Morphological Annotation}

At the first step of our study we prepare morphologically annotated sentence-aligned parallel texts. The Slovak texts are morphologically annotated automatically by the tagger Morče which has been trained and tuned on tagset, developed by the Slovak National Corpus (Garabík \& Šimková, 2012).

For analysis of Bulgarian morphology, we used the Bulgarian parameter file for the Tree-Tagger (Schmid, 1997), using the tagset from the BulTreeBank project (Simov, Osenova, \& Slavcheva, 2004).

\subsection{Alignment}

The bilingual sentence-aligned corpora are valuable resources for many NLP applications: for machine translation research, for searching/extracting of language data, and can be also used as a translation database and language learning materials for training of translators - human and programming tools. The web-presented bilingual aligned corpora are available and oriented both to human and machine users. Such corpora and derived from them special type of lists, as frequency lists and concordances, are useful for language teaching. Concordances have also many applications in contrastive studies: they are used for comparison of different uses of the same word (in a different context), and to locate and analyse phrases and idioms in a given text; to find the translation of the essential elements of text, such as terms (in multilingual texts).

To align the text on the sentence level, we use the hunalign software (Varga et al., 2005). The uses a corresponding bilingual Slovak-Bulgarian dictionary to ensure a higher accuracy of the alignment; we used a small bootstrapped dictionary that has been generated automatically and then manually proofread, removing incorrect word pairs. Alignment on the word level was performed using the GIZA ++ software (Och \& Ney, 2000), using (for simplicity) only sentence pairs where the alignment was 1:1. Generally, word alignment is M:N (any number of Bulgarian words can map to any number of Slovak ones), although only 1:1 and realistically at most 1:2 (and 2:1) appear in our corpus texts. 


\section{Phrases Extraction}

We use the MOSES (Koehn et al., 2007), a statistical machine translation toolkit to process the corpus. The toolkit uses GIZA ++ to obtain an initial word alignment which is subsequently improved by a "grow-diag-final" method.

Throughout this article, we use the term 'phrase' following the MOSES terminology, i.e. a phrase is a short sequence of one or several words that has been selected from the text corpus (and aligned with a corresponding text chunk phrase - from the second language part of the corpus), and has no connection with a 'phrase' as a term in general linguistics. Although MOSES could be used to build a machine translation system based on our corpus, this was not our goal and we used only the training process which produces aligned and scored bilingual phrase tables.

MOSES training produces four different phrase translation scores:

- inverse phrase translation probability $\varphi(f \mid e)$

- inverse lexical weighting lex $(f \mid e)$

- direct phrase translation probability $\varphi(e \mid f)$

- direct lexical weighting lex $(e \mid f)$

Ideally, we would like to compute a single score out of these four numbers, reflecting the level of "suitability" of the phrase pair. Since we designed our interface to be language-direction agnostic (i.e. conceptually neither Bulgarian $\rightarrow$ Slovak nor Slovak $\rightarrow$ Bulgarian correspondence should be favoured), and since we want to take into account not just phrase correspondence, but also correspondence of individual words, our score must be symmetrical with regard to $\varphi(f \mid e)$ and $\varphi(e \mid f)$, as well as to $l e x(f \mid e)$ and $l e x(e \mid f)$, and should reflect the likelihood-like nature of these scores. The simplest function that fulfils these criteria is a simple product, $g=\varphi(f \mid e) \cdot \varphi(e \mid f) \cdot \operatorname{lex}(f \mid e) \cdot l e x(e \mid f)$.

In order to be able to quantify the correctness of extracted phrases, we split the phrases into sets according to logarithm of the score $g$, in intervals two orders of magnitude wide, i.e.

$$
g \in\left(10^{-30}, 10^{-28}\right] \cup \ldots \cup\left(10^{-6}, 10^{-4}\right] \cup\left(10^{-4}, 0.01\right] \cup(0.01,1]
$$

In each interval, we randomly selected 10 sentences (population sample) and manually annotated their correspondence, selecting between three options: good, bad and not sure. In the interval $\left[10^{-14}, 10^{-6}\right]$ we increased the number of sentences to 30 , to get better estimates. Since the sampling of sentences from each interval is without replacement, the probability distribution is hypergeometric; however the number of sentences in each interval (population) is on the order of millions and therefore we can approximate the distribution by a binomial one (this is relevant for confidence interval estimation). For each of the intervals, we calculate the ratio:

$$
r=\frac{C(\text { good })}{C(\text { good })+C(\text { bad })-C(\text { notsure })}
$$

i.e. we remove the "not sure" sentence pairs from the sample and calculate the ratio of good ones. In order to get a function describing relation of the parameter $r$ to the 
score $g$, we start with several basic assumption. First, phrases with $g=1$ should be perfect equivalents, $r(g=1)=1$. Phrase pairs with very low score should be completely bogus:

$$
\lim _{g \rightarrow 0^{+}} r(g)=0
$$

We are therefore looking for a sigmoid function whose values start at zero at zero and saturates when approaches 1 . Since we are operating on intervals defined by orders of magnitude, we use the sigmoid function on domain $\ln (x)$. Generic logistic function is defined by:

$$
f(x)=\frac{1}{1+e^{-a \cdot\left(x-x_{0}\right)}}
$$

where $x_{0}$ is the centre of the function (horizontal shift) and a reflects the slope ('steepness'). Using the logistic function of a variable $x^{\prime}=\ln (x)$ and simplifying we get

$$
f(x)=\frac{1}{1+\frac{e^{a x_{0}^{\prime}}}{x^{a}}}
$$

We then fit our data points with the function (2) to obtain the parameters $a$ and $x_{0}^{\prime}$, which gives us:

$$
\begin{aligned}
& a=0.142 \pm 0.021 \\
& x_{0}^{\prime}=-35.0 \pm 1.2
\end{aligned}
$$

and subsequently $x_{0}=e^{x_{0}^{\prime}}=6.3 \cdot 10^{-16}$, i.e. the ratio of incorrectly aligned phrase pairs will reach 0.5 around $g=6.3 \cdot 10^{-16}$. The relation between the score $g$ and the ratio $r$ of our population samples is depicted on Fig. 2, together with the function (2).

We can use the function (2) to obtain the value of parameter $g$ where the ratio of correctly aligned phrases drops below certain value - we decided to keep $95 \%$ accuracy, so solving the equation

$$
r_{0}=0.95=\frac{1}{1+\frac{e^{a x_{0}^{\prime}}}{x^{a}}}
$$

for $x$ gives us a threshold $g_{0}=6.4 \cdot 10^{-7}$ for the desired $95 \%$ accuracy. ${ }^{1}$

After applying the above mentioned threshold, we examined the phrases we obtained, sorted by the score $g$. At the beginning we have phrase pairs with $g=1$. This implies that all the factors have to equal one: $\varphi(f \mid e)=\varphi(e \mid f)=l e x(f \mid e)=$ $l e x(e \mid f)=1$. In essence, this means that both Bulgarian and Slovak phrase match

\footnotetext{
${ }^{1}$ Note that although the uncertainties of $a$ and $x_{0}^{\prime}$ in equation (4) are small in relative values, the parameters themselves are in the exponent and the uncertainty has an enormous effect on absolute value of the function. This analysis should therefore be considered just a very rough estimation.
} 


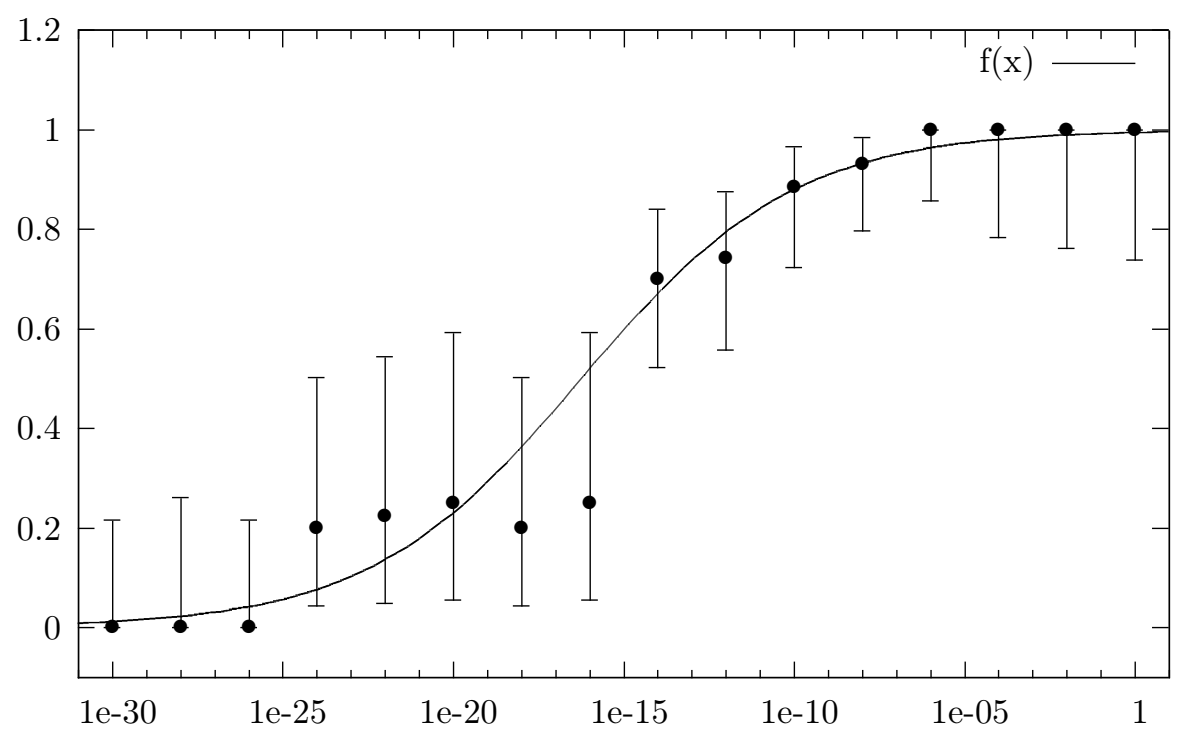

Figure 2: Relation between phrase alignment score $g$ (horizontal) and the ratio of good pairs $r$ (vertical). Vertical error bars display Jeffreys intervals at $95 \%$ confidence level (Brown, Cai and DasGupta, 2001).

perfectly - they occur always in the same form, and all the words of the phrases are always translated in the same way. This happens most of the time if there is a (often unique) foreign language (i.e. neither Bulgarian nor Slovak) citation, such as a name of a company or product (most striking are those in a foreign script, e.g. Greek occurs relatively often). Since "normal" sentences do not appear here at all, we included a condition $g \supsetneqq 1$ in our filter (such "foreign script" phrases would be excluded by following filters anyway).

Additional heuristic filtering consists of excluding phrases that:

- do not start with a letter

- contain punctuation (apart from a comma)

- are not exactly 4 words long

- contain more than 3 words starting with a capital letter

- end with a preposition

- contain characters out of the appropriate alphabet (Slovak or Bulgarian)

\section{Search Interface}

After filtering, we got 80 thousand phrase pairs, which we indexed by words and lemmas for our dictionary query system - keys (headwords) for each phrase consist of a union of lemmas and word forms from both Bulgarian and Slovak phrase, and their equivalents without diacritics (for Slovak) and transliteration into Latin script (for Bulgarian), to facilitate queries for users without ways of entering Cyrillic or 


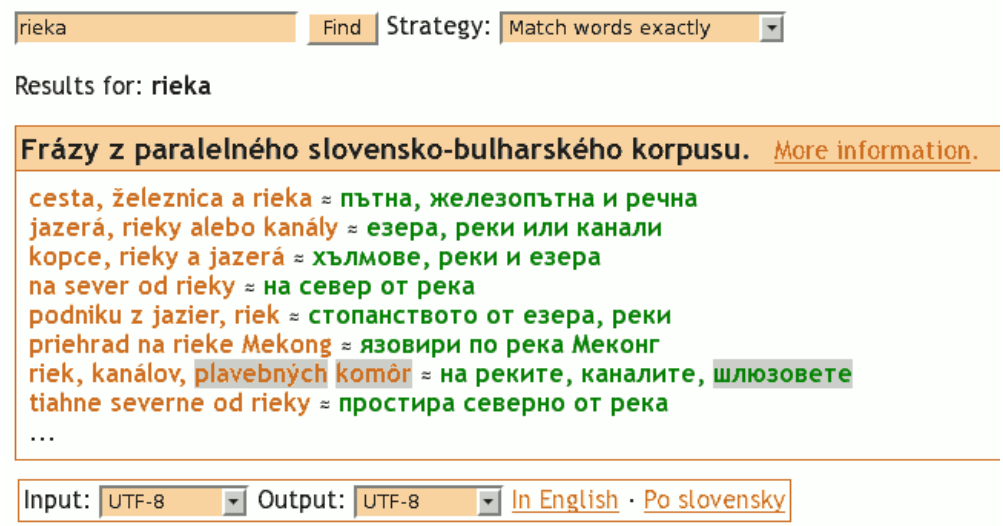

Figure 3: Fragment of the search interface, queried word rieka. Note the highlighted example of word alignment, plavebných komôr and шлюзовете, featuring 2:1 correspondence.

Slovak diacritics. The amount of words in the database is 350 thousand (per each language). Counting unique word forms, the size is 31 thousand in the Slovak part of the dictionary, 26 thousand in the Bulgarian part.

For the dictionary access, we are using the dict (RFC 2229) server ${ }^{2}$ as a backend, with a CGI frontend formatting the results in an intuitive and graphically representative way (see Fig. 3). The interface is accessible at http://slovniky . korpus.sk/?d=pskbg.

\section{Conclusion}

This paper presents results of an experimental study, namely automatic extraction and presentation of bilingual correspondences from Slovak-Bulgarian/BulgarianSlovak parallel and aligned corpus. The parallel Slovak-Bulgarian corpus, currently under development, is a valuable bilingual resource for language analysis, automatic term extraction, the research and development of machine and human translation systems, supervised and unsupervised NLP tools training, and machine translation.

\section{References}

Brown, L. D., Cai, T. T., \& DasGupta, A. (2001). Interval estimation for a binomial proportion. Statistical Science, 101-117.

Dimitrova, L., \& Garabík, R. (2011). Bulgarian-Slovak Parallel Corpus. In Natural Language Processing, Multilinguality: Proceedings of the 6th International Conference SLOVKO 2011, Modra, Slovakia (pp. 44-50).

Dimitrova, L., \& Garabík, R. (2012). Bilingual corpus - digital repository for preservation of language heritage. In Proceedings of the International Conference Digital Presentation and Preservation of Cultural and Scientific Heritage DiPP 2012, Veliko Türnovo, Bulgaria (pp. 132-141).

\footnotetext{
${ }^{2}$ http://dict.org
} 
Dimitrova, L., \& Garabík, R. (2014). Translation equivalence of demonstrative pronouns in Bulgarian-Slovak parallel texts. Cognitive Studies / Études cognitives, 14, 65-74. http://doi.org/10.11649/cs.2014.007

Garabík, R. \& Šimková, M. (2012). Slovak morphosyntactic tagset. Journal of Language Modelling, 0(1), 41-63. http://doi.org/10.15398/jlm.v0i1.35

Garabík, R., Dimitrova, L., \& Koseska-Toszewa, V. (2011). Web-presentation of bilingual corpora (Slovak-Bulgarian and Bulgarian-Polish). Cognitive Studies / Études cognitives, 11, 227-239.

Garabík, R., Majchráková, D., \& Dimitrova, L. (2009). Comparing Bulgarian and Slovak Multext-East morphology tagset. In Organization and development of digital lexical resources (pp. 38-46). Kyiv. Dovira Publishing House.

Koehn, P., Hoang, H., Birch, A., Callison-Burch, C., Federico, M., Bertoldi, N., Cowan, B., Shen, W., Moran, C., Zens, R., Dyer, C., Bojar, O., Constantin, A. and Herbst, E. (2007). Moses: Open Source Toolkit for Statistical Machine Translation, Annual Meeting of the Association for Computational Linguistics (ACL), demonstration session, Prague, Czech Republic, June $200 \%$.

Och, F. J. \& Ney, H. (2000). Improved statistical alignment models. In Proceedings of the 38th Annual Meeting on Association for Computational Linguistics (pp. 440-447). Stroudsburg, PA: Association for Computational Linguistics. http://doi.org/10. 3115/1075218.1075274

Schmid, H. (1997). Probabilistic part-of-speech tagging using decision trees. In D. Jones \& H. Somers (Eds.), New methods in language processing (pp. 154-164). London: UCL Press. (Studies in Computational Linguistics).

Simov, K., Osenova, P., \& Slavcheva, M. (2004). BTB-TR03: BulTreeBank Morphosyntactic Tagset. BulTreeBank Project Technical Report № 03. Technical report, Linguistic Modelling Laboratory, Bulgarian Academy of Sciences.

Varga, D., Németh, L., Halácsy, P., Kornai, A., Trón, V. \& Nagy, V. (2005). Parallel corpora for medium density languages. In Proceedings of the RANLP 2005 (pp. 590$596)$.

\section{Acknowledgment}

This work was supported by a bilateral project "Electronic Corpora - Contrastive Study with Focus on Design of Bulgarian-Slovak Digital Language Resources (continuation of the project)" as part of the collaboration between Institute of Mathematics and Informatics of the Bulgarian Academy of Sciences and L'. Štúr Institute of Linguistics of the Slovak Academy of Sciences.

The authors declare that they have no competing interests.

The authors' contribution was as follows: Both authors participated in the manuscript; RG focused on technical work and mathematical representation of the ideas, LD on text alignment and accuracy evaluation.

This is an Open Access article distributed under the terms of the Creative Commons Attribution 3.0 PL License (http://creativecommons.org/licenses/by/3.0/pl/), which permits redistribution, commercial and non-commercial, provided that the article is properly cited.

(C) The Authors 2015

Publisher: Institute of Slavic Studies, PAS, University of Silesia \& The Slavic Foundation 